\title{
Embedded Mesoporous Silica Silver Nanoparticles as potential antibacterial agent againstMultidrug-Resistant Bacteria
}

\author{
${ }^{1}$ Sanaa S. Zaki, ${ }^{2}$ Kheiralla Z. H., ${ }^{3}$ Rushdy A. A, ${ }^{4}$ Betiha M.A. and ${ }^{5}$ Hanan B. \\ Abousittash \\ 1- Botany Department- Faculty of Women for Arts, Science and Education Ain \\ Shams University, AsmaaFahmy,Cairo,Egypt \\ e-mail:sanaasobhy_2011@yahoo.com, e-mail:kheiralla@hotmail.com,e-mail:_ \\ abeerahmedr@gmail.com, e-mail: habostash@gmail.com. \\ 2- Egypt Refining Division, Egyptian Petroleum Research Institute, Cairo,Egypte- \\ mail:Mohamed_betiha@hotmail.com
}

\begin{abstract}
Many workers have paid more attention to eco-friendly mesoporous silica silver nanoparticles featuring smaller particle sizes to enhance their remarkable antimicrobial properties. A simple chemical method was developed for synthesize high valence silver nanoparticles immobilized on the mesoporoussilica nanomaterial, which showed strong antibacterial activity. Chemical reduction of silver ion has been regarded in the present work, and a reducing agent, such as hydrazine was used to promote the reduction of the silver ion - precursor. The average particle size of the synthesized mesoporous silica-silver nanoparticles $\left(\mathrm{Ag} / \mathrm{NH}_{2}-\mathrm{KIT}-6(\mathrm{x})\right)$ with different concentrations of $\mathrm{Ag}$ (3.2 and 7.1\%) calculated from Scherrer's equation for (1 111$)$ plane were 8 and $6.5 \mathrm{~nm}$ respectively. The synthesized materials were characterized using X-Ray diffraction (XRD), FTIR spectra, X-ray photoelectron spectroscopy (XPS) and transmission electron microscopy (TEM), which revealed the mesoporous silica nanoparticles.
\end{abstract}

Antibacterial activities of mesoporous silver nanoparticles against Gramnegative Pseudomonas aeruginosa(ATCC 9027) and Gram-positive Staphylococcus aureus(ATCC 43300) were found to be increased with the increasing of $\mathrm{Ag}$ concentration in the $\mathrm{Ag} / \mathrm{NH}_{2}-\mathrm{KIT}-6(\mathrm{x})$. The maximum inhibition zone diameter when the concentration $7.1 \%$ was used obtained against $P$. aeruginosaand $S$. aureuswith diameters of 32 and $30 \mathrm{~mm}$ respectively. The antimicrobial activity of mesoporousAg/ $\mathrm{NH}_{2}-\mathrm{KIT}-6(\mathrm{x})$ was evaluated also using the MIC\&MBC tests. The surface structures of both the untreated and the treated bacterial cells were examined by the aid of TEM. The treated bacterial cells were significantly changed, and major damage was observed in the outer cell membrane. In conclusion the use of AgNPs as antibacterialagentwasfoundtobetoxicagainstpathogenicbacteriaandconsidered

\section{Corresponding author: \\ e-mail: habostash@gmail.com}


advantageous over other methods for control of pathogenic microorganisms, and it can be of great importance in developing novel drugs for curing many lethaldiseases.

Key word: Mesoporous Silica-Silver Nanoparticles, Antimicrobial activity, Drug resistance

\section{Introduction}

Increasing hospital and community-acquired infections due to bacterial multidrug-resistant (MDR) pathogens for which current antibiotic therapies are not effective and represent a growing problem. Antimicrobial resistance and biofilm development in affected patients is thus one of the major threats to human health, since it determines an increase of morbidity and mortality as a consequence of the most common bacterial diseases (Klevenset al., 2007 and Walker et al.,2009).

Mesoporous silica nanoparticles (MSNs) are well known for their biocompatibility, dispersibility, and chemical stability as carriers for drug/gene/antimicrobial agents. They have also been used as cell markers, catalytic substrates, absorbents, and matrix fillers (Ruedas-Rama et al., 2012; Yildirimet al., 2013; Natarajan and Selvaraj, 2014 and Chen et al., 2014). They can be synthesized with controlled size, shape and varying textural properties (e.g. pore size, surface area and porosity) for therapeutic uses (Wu et al., 2013 and Qasimet al., 2014). Porous materials are of great interest because of their ability to interact with atoms, ions, molecules and nanoparticles not only at their surfaces, but throughout the bulk of the materials. Therefore, the presence of pores in nanostructured materials greatly promotes their physical and chemical properties (Han et al.,2011).

Nanoparticles are now considered a viable alternative to antibiotics and seem to have a high potential to solve the problem of the emergence of bacterial multidrug resistance (Raiet al., 2012). Metal nanoparticles of silver, copper, and gold have been found to be active against certain pathogenic bacteria and fungi. In particular, silver nanoparticles (AgNPs) have attracted much attention in the scientific field.

Silver has always been used against various diseases, in the past it was used as an antiseptic and antimicrobial against Gram-positive and Gram-negative bacteria (Taraszkiewiczet al., 2012 and Franciet al., 2015). Comparatively, AgNPs have been intensely studied owing to their distinct properties such as conductivity, chemical stability, catalytic activity, nonlinear optical behavior, low cytotoxicity and strong inhibitory and bactericidal effects as well as a broad spectrum of antimicrobial activities. These properties make them suitable for use as an antimicrobial agent in catheters, burns, severe chronic osteomyelitis, urinary tract infections and medical textiles.

Mesoporous silica AgNPs were considered, particularly attractive for the production of a new class of antimicrobials opening up a completely new way to combat a wide range of bacterial pathogens (Sweet and Singleton, 2011 and Raiet

\section{Corresponding author: \\ e-mail: habostash@gmail.com}


al., 2016). The production of mesoporous Silica - AgNPs is relatively inexpensive and the addition of these particles into goods such as plastics, clothing, creams, and soaps increase their market value (Fenget al., 2000).

The aim of the work presents an overview of mesoporous silica-silver nanoparticles preparation by chemical methods and the implications of their use in controlling pathogenic microbes as they were tested for their antibacterial efficacy for different multidrug-resistant bacterial strains.

\section{Materials and Methods}

\section{Chemicals}

PluronicP123 (triblockcopolymer $\mathrm{P} 123, \mathrm{EO}_{20} \mathrm{PO}_{70} \mathrm{EO}_{20}, \mathrm{Mw}$ of $\approx 5800$ ), tetraethyl orthosilicate (TEOS, $\geq 99.0 \%$ ),3-Aminopropyltrimethoxysilane (APTS, 97\%), 2,4,6-trinitrobenzenesulfonic acid (TNBS, $1 \mathrm{M}$ in $\mathrm{H}_{2} \mathrm{O}$ ), potassium tetraboratetetrahydrate $\left(\mathrm{K}_{2} \mathrm{~B}_{4} \mathrm{O}_{7}, \geq 99.5 \%\right)$, tetrabutylammoniumbromide ( $\geq 98 \%), \quad$ 1-butanol ( $\geq 99 \%), \quad \mathrm{HCl} \quad$ (35wt. \%), hydrazine hydrate, silver acetate(99.99\%),1,2,4-trimethylbenzene solvents including methanol and ethanol were purchased from Sigma-Aldrich and used without furtherpurification.

\section{Synthesis of High Valence of Mesoporous Silica Silver Nanoparticles}

The KIT-6 was synthesized as reported by Qianet al. (2012) and Hassan et al. (2016) with some modification. Ten $g$ of PluronicP123 were melted $\left(75^{\circ} \mathrm{C}\right)$ and then dissolved in $300 \mathrm{ml}$ distilled water and $35 \mathrm{ml} \mathrm{HCl}$ (35 wt. \%). The mixture was sheared at $350 \mathrm{rpm}$ for $1 \mathrm{~h}$. at $35^{\circ} \mathrm{C}$ then, $10 \mathrm{ml}$ of 1-butanol and $1 \mathrm{ml}$ of $1,2,4-$ trimethylbenzenewere added at once to the stirred mixture for $30 \mathrm{~min}$. at $35^{\circ} \mathrm{C}$. After that, $20 \mathrm{~g}$ of TEOS was added to the stirred mixture and it was further stirred for $24 \mathrm{~h}$. at $35^{\circ} \mathrm{C}$. Then, the mixture was transferred to $500 \mathrm{ml}$ Teflon autoclave and the hydrothermal process was carried out for $48 \mathrm{~h}$. at $130^{\circ} \mathrm{C}$ under static conditions. The dried obtained white material after filtration and washing with mixture of water and ethanol was finally calcinedin air atmosphere at $600{ }^{\circ} \mathrm{C}$ for $8 \mathrm{~h}$.

The obtained free surfactant KIT-6 was coupled with APTS to functionalize the KIT-6 pores with propylaminemoieties as following, $2.0 \mathrm{~g}$ of APTS was added directly to $5.0 \mathrm{~g}$ of degassed KIT- 6 in $150 \mathrm{ml}$ dry toluene under mechanicalstirring for $4 \mathrm{~h}$, at ambient temperature and then refluxed for another $12 \mathrm{~h}$. The obtained material $\mathrm{NH}_{2}$-KIT-6 was recovered by centrifuge, washed several times with ethanol- water mixture $(50 / 50 \mathrm{~V} / \mathrm{V})$ to remove unreacted APTS molecules and vacuum dried at $60^{\circ} \mathrm{C}$ overnight (Hassan et al.,2014).

The amino groups functionalized KIT-6 was determined gravimetrically by using, 2, 4, 6-trinitrobenzenesulfonic acid (Weber et al., 2000). The degassed $\mathrm{NH}_{2}-$ KIT-6 $(0.1 \mathrm{~g})$ was suspended in double distilled water $(1 \mathrm{ml})$ at $50^{\circ} \mathrm{C}$ for $2 \mathrm{~h}$ and left tocool.Then, thesuspended $\mathrm{NH}_{2}$-KIT-6wasfurtherdilutedwith5mlof $100 \mathrm{mmol}$

\section{Corresponding author: \\ e-mail: habostash@gmail.com}


borate buffer $\left(\mathrm{K}_{2} \mathrm{~B}_{4} \mathrm{O}_{7} ; \mathrm{pH}=9.3\right)$, and $1.5 \mathrm{ml}$ of $1000 \mathrm{mmol}$ TNBS solution was added and allowed to react for $4 \mathrm{~h}$ at $35{ }^{\circ} \mathrm{C}$. After that, the $\mathrm{NH}_{2}-\mathrm{KT}-6$-was recovered by centrifuge at $14000 \mathrm{rpm}$ for $5 \mathrm{~min}$. The supernatant absorption was measured at 350 $\mathrm{nm}$ to determine the concentration of TNBS molecules. Reference samples were prepared in parallel composed of $6 \mathrm{ml}$ of double distilled water of $\mathrm{K}_{2} \mathrm{~B}_{4} \mathrm{O}_{7}$ material without $\mathrm{NH}_{2}$-KIT-6 material, and the concentration of amino was confirmed with TNBS solutions.

The doping of silver nanoparticle (AgNPs) on $\mathrm{NH}_{2}$-KIT-6 at different loading was prepared in dry toluene using tetrabutylammonium bromide as cationic surfactant and silver acetate as a silver precursor. Briefly, $1.0 \mathrm{~g}$ of $\mathrm{NH}_{2}$-KIT-6 (1.628 mmol of $\mathrm{NH}_{2}$ ) was suspended in $10 \mathrm{ml}$ of toluene under ultrasonic irradiation for $15 \mathrm{~min}$, and 5 $\mathrm{ml}$ of aqueous containing $0.25 \%$ tetrabutylammonium bromide and $6 \mu \mathrm{l}$ of hydrazine are added and the mixture was further sonicated for additional $5 \mathrm{~min}$. A $0.138 \mathrm{~g}(0.81$ $\mathrm{mmol}$ ) of silver acetate in $5 \mathrm{ml}$ of distilled water was injected into the sonicated mixture under vigorous stirring. The mixture color slowly turned from white to pink, ruby and dark red color, confirming formation of AgNPs. The mixture temperature is raised to $45^{\circ} \mathrm{C}$ to ensure the compellation of reaction for $2 \mathrm{~h}$, and the solvents were drained under vacuum at $80^{\circ} \mathrm{C}$. After solidification, the obtained sample was washed several times with water-ethanol $(90 / 5 ; \mathrm{V} / \mathrm{V})$ until free tetrabutylammonium bromide was detected by $\mathrm{AgNO}_{3}$. Finally, the obtained sample was dried under vacuum for 6 h. AgNPs immobilized in $\mathrm{NH}_{2}$-KIT-6 was stirred in $10 \% \mathrm{HNO}_{3}$ and analyzed by Inductive Coupled Plasma (ICP). The samples were donated as $\mathrm{Ag} / \mathrm{NH}_{2}-\mathrm{KIT}-6$ (x), where $\mathrm{x}$ represents the weight ratio of $\mathrm{Ag}^{\mathrm{o}}$ immobilized on $\mathrm{NH}_{2}$-KIT-6 3.2 and $7.1 \%$.

\section{Characterization of Mesoporous Silica Silver Nanoparticles}

The XRD patterns were performed in X'Pert PRO instrument using $\mathrm{Cu} \mathrm{K} \alpha$ radiation at $40 \mathrm{kV}$ and $30 \mathrm{~mA}$. In powder XRD patterns, the positions of the peaks are determined only by the dimensions and shape of the unit cell (McCusker and Baerlocher, 2001 and Rai and Duran, 2011) and in general the intensities depend on the type of atoms and their position within the unit cell. Diffractograms were obtained from 0.5 to $10(2 \square)$ at a scanning speed of $0.05 \mathrm{deg} . \mathrm{min}^{-1}$ and counting time of $5 \mathrm{~s}$.

The $\mathrm{N}_{2}$-adsorption isotherms were performed at $-196{ }^{\circ} \mathrm{C}$ in NOVA 3200 system instrument. The specific surface area was measured by applying the BET equation to the adsorption isotherm in regime $\geq 0.35$ of $\mathrm{P} / \mathrm{P}_{0}$ value. The pore sizedistribution was calculated from Barrett-Joyner-Halenda (BJH) method. The total pore volume was considered to be the volume of liquid $\mathrm{N}_{2}$ adsorbed at a relative pressure of 0.98. Prior to the analysis, the samples were outgassed under vacuum at $140^{\circ} \mathrm{C}$ for at least $16 \mathrm{~h}$. High Resolution Transmission Electron Microscope images were obtained on a JEOL JEM 2100 microscope. Transmission Electron Microscope

\section{Corresponding author:


samples were prepared by sonication of the powder in ethanol and evaporating one drop onto a holey carbon film.

The FTIR spectra were recorded on a Nicolet iS10 Fourier transform infrared spectrophotometer. X-ray photoelectron spectroscopy (XPS) was carried out using a Thermo Scientific K-ALPHA USA instrument equipped with a dual X-ray source, using the $\mathrm{AlK} \alpha$ radiation anode and a hemispherical energy analyzer. With an analyzer chamber pressure of $10^{-9}$ torrat a power of $250 \mathrm{~W}$. Metal' s concentration impregnated in the samples was quantitatively determined using standard methods of analyses including Inductive Coupled Plasma (ICP). The ICP instrument is ICP-OES Perkin-Elmer Optima 2000DV.

\section{Microbiological Experiments}

\section{Bacterial Cultures}

Two Pathogenic bacterial strains, Gram negative Pseudomonas aeruginosa(ATCC9027) and Gram positive Staphylococcus aureus(ATCC43300) obtained from American type (ATCC,US) culture collection were used in this study. During the experimental period, the cultures were grown on nutrient agar and maintained at $4^{\circ} \mathrm{C}$. For long term preservation, the cultures were stored in vial tubes containing $1 \mathrm{ml}$ aliquots plus $20 \%$ glycerol at $-20^{\circ} \mathrm{C}$ (EL-Batalet al., 2013). Bacterial cultures at the log phase of growth were prepared in nutrient broth after $16 \mathrm{~h}$. of incubation at $37^{\circ} \mathrm{C}$.

\section{Antibacterial Susceptibility Testing}

Eight different antibiotics including Cefodizime (CFZ) 30 $\mu$ g, Cefoperazone

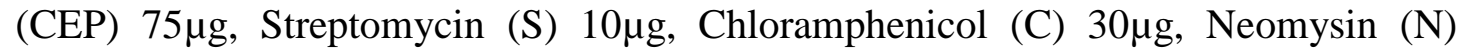
$30 \mu \mathrm{g}$, Sulfamethoxazole-trimethoprim (SXT) $25 \mu \mathrm{g}$, Nalidixicacid (NA) 30 $\mu \mathrm{g}$ and Colifuran (F) $200 \mu \mathrm{g}$ as standard antibacterial agents were used and antibacterial susceptibility test was performed by disk diffusion method on Mueller-Hinton agar plates according to Kheirallaet al.(2014).

\section{Assessment of the Antibacterial Activity of Mesoporous Silica Silver Nanoparticles}

The antimicrobial efficacy of silver nanoparticles with different concentrations (3.2 and 7.1\%) was tested against Pseudomonas aeruginosaand Staphylococcus aureusby:

a- Well DiffusionTest:

Plates of Mueller-Hinton agar were inoculated using a sterile swab to produce a confluent lawn of growth. Using sterile cork borer, the well $(6 \mathrm{~mm})$ was made into

\section{Corresponding author: \\ e-mail: habostash@gmail.com}


each Petri dish. A $50 \mu \mathrm{l}$ of (Ag/ NH2-KIT-6(x), 100 $\mu \mathrm{g} / \mathrm{ml})$ suspended into dimethyl sulfoxide (DMSO) was put into the wells, and then the plates were left at refrigerator for 3 hours to allow diffusion of the test sample. The plates were incubated for 18-24 h. at $370 \mathrm{C}$ and the inhibition zones were measured, (DMSO) was used as a negative control according to Iconaru et al. (2012).

\section{b- Minimum Inhibitory Concentration (MIC) and Minimum Bactericidal Concentration (MBC)Test:}

The minimum inhibitory concentration and $\mathrm{MBC}$ of silver nanoparticles were assessed by the macro dilution broth susceptibility test according to the method based on the US National Committee for Clinical Laboratory Standards Guidelines, with modifications incorporated for nanomaterials by Karthikeyanet al. (2011) and Kheirallaet al. (2014). Sterile Mueller-Hinton broth was used as diluents for the preparation of silver nanoparticles dilution. A serial dilution of the $0.01 \mathrm{mg} / \mathrm{ml}$ silver nanoparticles solution was prepared within a desired range .One milliliter of each bacterial suspension that was prepared by suspending colonies from an overnight cultured tested bacteria on nutrient agar in sterile saline solution $(0.85 \% \mathrm{NaCl})$ and adjusting turbidity to $0.5 \mathrm{McFarland}\left(2 \times 10^{6} \mathrm{CFU} / \mathrm{ml}\right)$ was inoculated and then tubes were incubated for $24 \mathrm{~h}$. at $37^{\circ} \mathrm{C}$, the control tubes without the silver nanoparticles were assayed simultaneously. Minimum inhibitory concentration is the lowest concentration of antimicrobial agents that inhibited 90 percent of the bacterial growth was examined visually by checking the turbidity of the tubes. To test the bactericidal effect a loopful from each tube was inoculated on Mueller-Hinton agar and incubated for $24 \mathrm{~h}$. at $37^{\circ} \mathrm{C}$. The nanoparticles concentration causing bactericidal effect was selected based on absence of colonies on the agar plate (Rupareliaet al., 2008). The results were plotted as the mean value of 3 mutually independent experiments.

\section{Action of Mesoporous Silica Silver Nanoparticles on the Ultrastructur of Bacterial Cells}

The effects of $\mathrm{Ag} / \mathrm{NH}_{2}-\mathrm{KIT}-6(\mathrm{x})$ on the morphology of both $P$. aeruginosaand $S$. aureuswere examined under transmission electron microscopy (TEM). Cells of $P$. aeruginosaand $S$. aureusbefore and after treatment with certain concentration of AgNPs representing the MIC for each were fixed overnight with $2.5 \%$ glutaraldehyde. Samples were post-fixed in $2 \%$ osmium tetroxide, dehydrated in an ascending series of graded ethanol, infiltrated and embedded in spur resin. Then, ultra-thin sections (60 $\mathrm{nm}$ thicknesses) were cut using ultra -microtome stained with uranyl acetate and counter-stained with $4 \%$ lead citrate. These sections were mounted on carbon-coated copper grids and observed under TEM (JEOL1010) (Grigor'evaet al.,2013).

\footnotetext{
Corresponding author:

e-mail: habostash@gmail.com
} 


\section{Statistical analysis}

The experiments were replicated three independent times and the data are presented as mean \pm STD. Statistical analysis was carried out using Student's t test. Differences were considered statistically significant when P-value was less than 0.01 .

After testing the data for normality, the differences in the treatments were tested using one-way analysis of variance (ANOVA 1) according to SPSS software (SPSS, 2006). A post-hoc test was applied when differences were significant.

\section{Results and Discussion}

Overuse or misuse of antimicrobial agents has led to the development of multi-drug resistant bacteria. To overcome the limitations of conventional synthetic antimicrobial compounds, nanotechnology represents an alternative strategy in developing alternative antimicrobial agents that can efficiently kill bacterial cells and display immense potential for use in both medical and veterinary applications (Yuan et al., 2017).

\section{Characterization of Mesoporous Silica Silver Nanoparticles}

The sol-gel technique is one of the most important facile methods for porous preparation materials. The ordered cubic pore of silicate was synthesized using TEOS as silica precursor, $\mathrm{HCl}$ as a hydrolysis catalyst, $\mathrm{P} 123$ as structure directing agent (PO moieties as phase separation inducers; PEO moieties as a gelling agent) and butanol as co-surfactant. The pore construction morphology is determined by the balance between the silica coarsening and the structure freezing by P123 and butanolcosurfactant that create the cubic morphology of the obtained monolithic silica. The second phase includes grafting of APTS on the silica in toluene, forming covalentbond between the monolithic silica and amino-organosilane moieties (Fig. 1). After that, the obtained amino-silicate $\left(\mathrm{NH}_{2}\right.$-KIT-6) was used as a platform to cap the reduced silver nanoparticle. In this stage, the silver acetate was embedded on $\mathrm{NH}_{2}-\mathrm{KIT}-6$, forming an $\mathrm{Ag}-\mathrm{NH}_{2}-\mathrm{SiO}_{2}$ complex, and an appropriate amount of hydrazine was used to promote the reduction of the silvercomplex. 

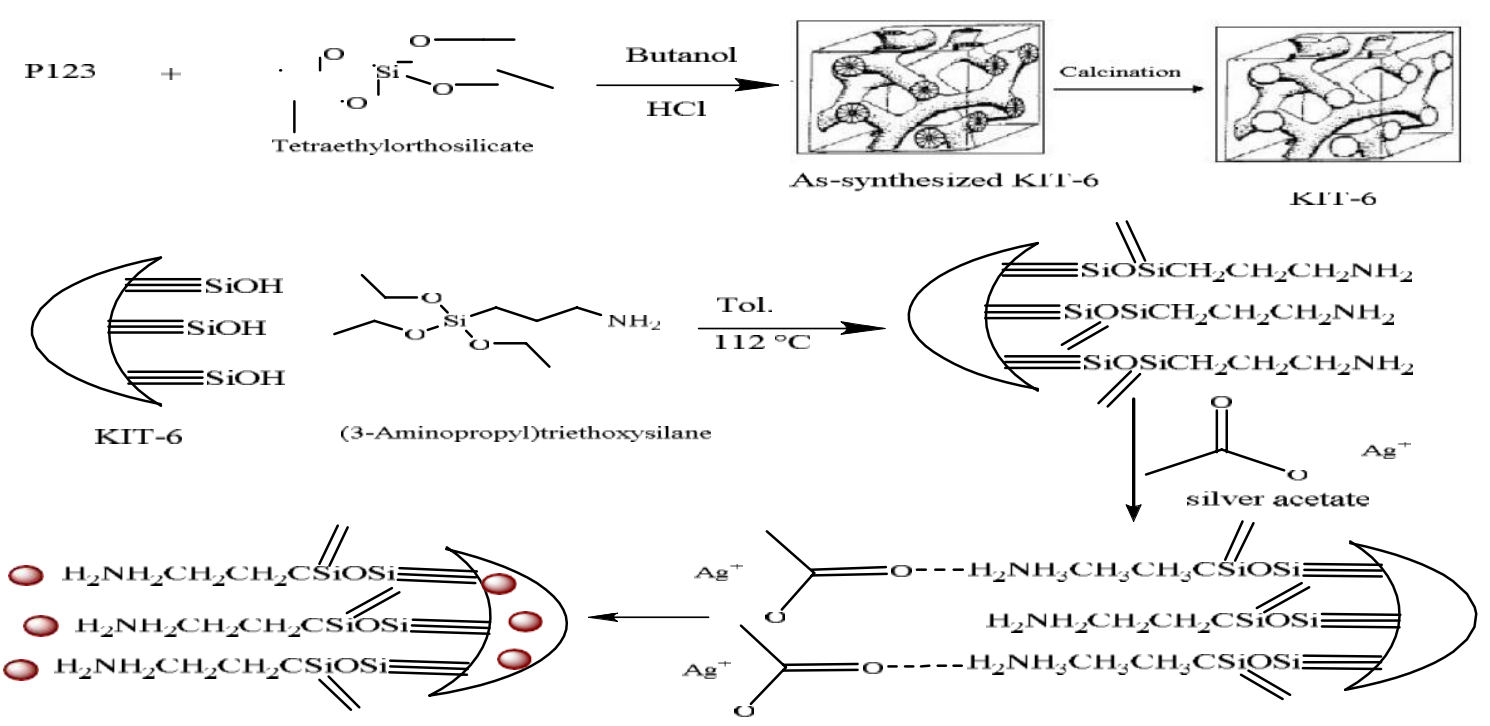

Fig.1: Schematic representation of the preparation of KIT-6, $\mathrm{NH}_{2}-\mathrm{KIT}-6$ and $\mathrm{Ag} / \mathrm{NH}_{2}-\mathrm{KIT} 6(\mathrm{x})$.

The concentration of amino group per gram was of $1.45 \mathrm{mmolg}^{-1}$ and the immobilized silver according to ICP analysis was of $7.1 \%$ and $3.2 \%$, for $\mathrm{Ag} / \mathrm{NH}_{2}-\mathrm{KIT}$ $6(7.1 \%)$ and $\mathrm{Ag}-\mathrm{NH}_{2}-\mathrm{KIT}-6(3.2 \%)$. The FTIR assembly details of the KIT-6 functionalized $\mathrm{NH}_{2}-\mathrm{KIT}-6$ and $\mathrm{Ag} / \mathrm{NH}_{2}-\mathrm{KIT}-6(\mathrm{x})$, were examined.Spectra of $\mathrm{NH}_{2}$ KIT-6 and Ag immobilized on Ag-NH$-\mathrm{KIT}-6(1.7 \& 3.2)$ are shown in Fig. 2 The KIT6, $\mathrm{NH}_{2}-\mathrm{KIT}-6$ and $\mathrm{Ag} / \mathrm{NH}_{2}-\mathrm{KIT}-6$ (7.1 and $\left.3.2 \%\right)$ exhibit the characteristic stretching broad bands associated with $\equiv \mathrm{Si}-\mathrm{OH}$ groups in the regime of $3450-3350 \mathrm{~cm}^{-1}$, while the corresponding binding band for KIT-6 \& $\mathrm{NH}_{2}$-KIT-6, are observed at 1665 $\mathrm{cm}^{-1}$ and $1650 \mathrm{~cm}^{-1}$ for $\mathrm{Ag} / \mathrm{NH}_{2}-\mathrm{KIT}-6$. The $\mathrm{NH}_{2}-\mathrm{KIT}-6$ exhibits the characteristic $\mathrm{CH}_{2}$ asymmetric and symmetric stretching bands near $2933 \mathrm{~cm}^{-1}$ and $2821 \mathrm{~cm}^{-1}$, respectively. While asymmetric $\mathrm{Si}-\mathrm{O}-\mathrm{Si}$ stretching bands appaired near $1066 \mathrm{~cm}^{-1}$, the band near $969 \mathrm{~cm}^{-1}$ is due to the $\mathrm{Si}-\mathrm{O}$ bending in the $\mathrm{Si}-\mathrm{OH}$ groups and asymmetric $\mathrm{Si}-\mathrm{O}-\mathrm{Si}$ stretching band appeared near $810 \mathrm{~cm}^{-1}$. The vibration band at $3137 \mathrm{~cm}^{-1}$ in $\mathrm{NH}_{2}$-KIT-6 is attributed to the stretching vibration of $-\mathrm{NH}_{2}$ that is in hydrogen bonding with $\mathrm{Si}-\mathrm{OH}$. The presence of asymmetric $-\mathrm{N}-\mathrm{H}$ bending vibration near 707 $\mathrm{cm}^{-1}$ confirms the incorporation of an amino group on the KIT- 6 material. The band at $1380 \mathrm{~cm}^{-1}$ associated with $-\mathrm{CH}_{2}$ vibration, can be seen for the samples containing aminopropylgroups containing silver metal (Coates, 2000 and Wang et al., 2005). However this band became more intense as Ag loading increase, implying free mobility of propylamine moieties after deposition $\mathrm{Ag}^{0}$ on- $\mathrm{Si}-\mathrm{OH}$.

Moreover, the significant reduction in band intensities at $3450-3350 \mathrm{~cm}^{-1}$, conformingconsumption of hydroxylgroup after $\mathrm{Ag}$ anchoringin $\mathrm{NH}_{2}$-KIT-6 surface, suggesting that portion of silver acetate is incorporated on $-\mathrm{SiO}_{2}$ moieties. Finally, the intensity of the characteristic absorption bands in the range1350-960

\section{Corresponding author:}


$\mathrm{cm}^{-1}$ are also observed for all the samples, indicating slight changes in the pore structures after adsorption, which may be because of inherent disorder in the virginand functionalized material structures (Sajabet al.,2011).

The low angle XRD patterns of KIT-6, $\mathrm{NH}_{2}-\mathrm{KIT}-6$ and $\mathrm{Ag} / \mathrm{NH}_{2}-\mathrm{KIT}-6$ (3.2 and $7.1 \%$ ) are shown in Fig.3 The KIT-6 and $\mathrm{NH}_{2}$-KIT-6 samples exhibit three wellresolved; one strong intense diffraction peak and two minor diffraction peaks that assigned to (2 11 1), (2 20 ) and (3 32 ) reflections, which can be indexed to $\overline{3} d$, suggesting high ordered cubic mesoporous structure. It is clear that the intense peaks are shifted to lower angle after grafting APRTS molecule and more shift is noticed after $\mathrm{Ag}^{+1}$ loading. This behavior is resulted from increase the pore wall due to the grafting $\mathrm{Ag}^{0}$ on propylaminemoieties. In addition, the $a_{0}$ (unit cell parameter) is increased after $\mathrm{Ag}^{0}$ immobilization on KIT-6, escorted by the shift of the intense peak $\left(\begin{array}{lll}2 & 1 & 1\end{array}\right)$ reflection to lower angle. The high angle XRD patterns of KIT-6, $\mathrm{NH}_{2}$-KIT6, Ag/ $\mathrm{NH}_{2}-\mathrm{KIT}-6(3.2,7.1 \%)$, are shown in Fig. 4. The XRD patterns of KIT-6 and $\mathrm{NH}_{2}$-KIT-6 showed broad peak centered at $23.11^{\circ}$, while very weak peaks of the $\mathrm{Ag}^{0}$ species in $\mathrm{Ag} / \mathrm{NH}_{2}-\mathrm{KIT}-6$ (3.2) materials is detected due to the high dispersion of silver on $\mathrm{NH}_{2}-\mathrm{KIT}-6$, while four peaks at $38.04^{\circ}, 44.29^{\circ}, 64.30^{\circ}$ and $77.39^{\circ}$

corresponding to $\left(\begin{array}{lll}1 & 1 & 1\end{array}\right),\left(\begin{array}{lll}2 & 0 & 0\end{array}\right),\left(\begin{array}{lll}2 & 2 & 0\end{array}\right)$ and $\left(\begin{array}{lll}3 & 1 & 1\end{array}\right)$ plane-reflections of fcc $\mathrm{Ag}^{0}$ nanostructure is noticed for $\mathrm{Ag} / \mathrm{NH}_{2}-\mathrm{KIT}-6(3.2 \%)$ material. The average particles size of AgNPs calculated from Scherrer's equation for ( $\left.\begin{array}{lll}1 & 1 & 1\end{array}\right)$-plane were of 8 and $6.5 \mathrm{~nm}$ for $\mathrm{Ag} / \mathrm{NH}_{2}-\mathrm{KIT}-6(7.1 \%)$ and $\mathrm{Ag} / \mathrm{NH}_{2}-\mathrm{KIT}-6(3.2 \%)$, respectively.

The HRTEM images of the prepared samples are shown in Fig. 5. The KIT-6 and $\mathrm{NH}_{2}$-KIT samples exhibited well $3 \mathrm{D}$ cubic ordered mesoporousmaterials. The $\mathrm{Ag}^{0}$ immobilized $\mathrm{NH}_{2}$-KIT showed ordered/disordered mesopores, however the irregular domains become predominant as $\mathrm{Ag}^{0}$ loading increased due to the significant adsorption of $\mathrm{Ag}^{0}$ particle on amino or silanolgroups. Moreover, the AgNPs appeared highly dispersed on $\mathrm{NH}_{2}$-KIT and took the direction of KIT-6 pores, and the particle size distribution of AgNPs was of 4-9 nmsize.

The $\mathrm{N}_{2}$ adsorption-desorption isotherms of KIT-6, $\mathrm{NH}_{2}-\mathrm{KIT}-6$ and $\mathrm{Ag} / \mathrm{NH}_{2}-$ KIT-6(3.2, 7.1\%) materials are shown in Fig. 6 and the textural properties are collected in Table 1. All samples displayed Type IV isotherms with pronounced capillary condensation at high relative $P / P_{0}$ and $\mathrm{H} 1$ hysteresis loop, indicating large uniform channel-like mesoporous with narrow pore size distribution. The BET of KIT6 was of $705 \mathrm{~m}^{2} \mathrm{~g}^{-1}$, however, after graftingAPRTS, the surface area decreased to 503 $\mathrm{m}^{2} \mathrm{~g}^{-1}$ and the sharp decrease is noticed after immobilization of AgNP. The BET of $\mathrm{Ag} / \mathrm{NH}_{2}$-KIT-6(3.2, 7.1) was of $315 \mathrm{~m}^{2} \mathrm{~g}^{-1}$ and $280 \mathrm{~m}^{2} \mathrm{~g}^{-1}$, implying good dispersion of AgNPin the inter-connected pore ofKIT-6.

The UV-Vis absorption of $\mathrm{NH}_{2}-\mathrm{KIT}$ and $\mathrm{Ag} / \mathrm{NH}_{2}-\mathrm{KIT}-6(3.2,7.1)$ materials are shown in Fig. 7 The bare $\mathrm{NH}_{2}$-KIT- didn't show any UV-Vis absorption, while $\mathrm{Ag} / \mathrm{NH}_{2}-\mathrm{KIT}-6(3.2 \%)$ and $\mathrm{Ag} / \mathrm{NH}_{2}-\mathrm{KIT}-6(7.1 \%)$ showedUV-Vis absorption at 413

\section{Corresponding author: \\ e-mail: habostash@gmail.com}


nmand $417 \mathrm{~nm}$, respectively due to the Mie Plasmon resonance excitation of $\operatorname{AgNP}($ Kim et al., 2006). As the concentration of AgNP increased, the Plasmon resonance peak showed slight red shift, indicating the AgNP particle becomes larger somewhat. However, the low difference in AgNP particle size is attributed to the chemicalcoordination and steric effectof amino groups grafted on KIT-6 materials that obstruct the further growth of silversize.

The XPS spectra were used to demonstrate chemical environment for carbon, nitrogen and silver elements Fig. 8 The high resolution XPS of C 1s is showed three peaks of binding energy at 284.28, 284.6 and $286.24 \mathrm{eV}$, appoint to $\mathrm{C}-\mathrm{C}, \mathrm{C}-\mathrm{H}$, and $\mathrm{C}-$ $\mathrm{N} \mathrm{sp}^{3}$ carbon, respectively. The XPS spectra in the $\mathrm{N} 1 \mathrm{~s}$ binding energy rangedisplayed the spin orbital single for $\mathrm{NH}_{2}$-KIT-6 and doublet for $\mathrm{Ag} / \mathrm{NH}_{2}-\mathrm{KIT}-6(7.1 \%)$ at 399.7 and $401.2 \mathrm{eV}$, indicating that electron transfer from nitrogen atom to metallic $\mathrm{Ag}^{0}$. These values are in agreement the presence of $-\mathrm{NH}_{2}$ and coordinated $-\mathrm{NH}_{2}$, as reported for other immobilized $\mathrm{Ag}^{0}$. The XPS profile of $\mathrm{Ag} 3 \mathrm{~d}$ is curve-fitted into doublet spin-orbital with $\approx 6 \mathrm{eV}$ separation, Ferrariaet al. (2010) centered at 367.6 and $373.5 \mathrm{eV}$, which assigned to $\mathrm{Ag} 3 \mathrm{~d}_{5 / 2}$ and $\mathrm{Ag} 3 \mathrm{~d}_{3 / 2}$ present on $\mathrm{NH}_{2}-\mathrm{KIT}-6$. In this study absence of the peaks at $\sim 368$ and $\sim 374$ eVindicates that all silver atoms are reduced(Gebeyehuet al.,2016).

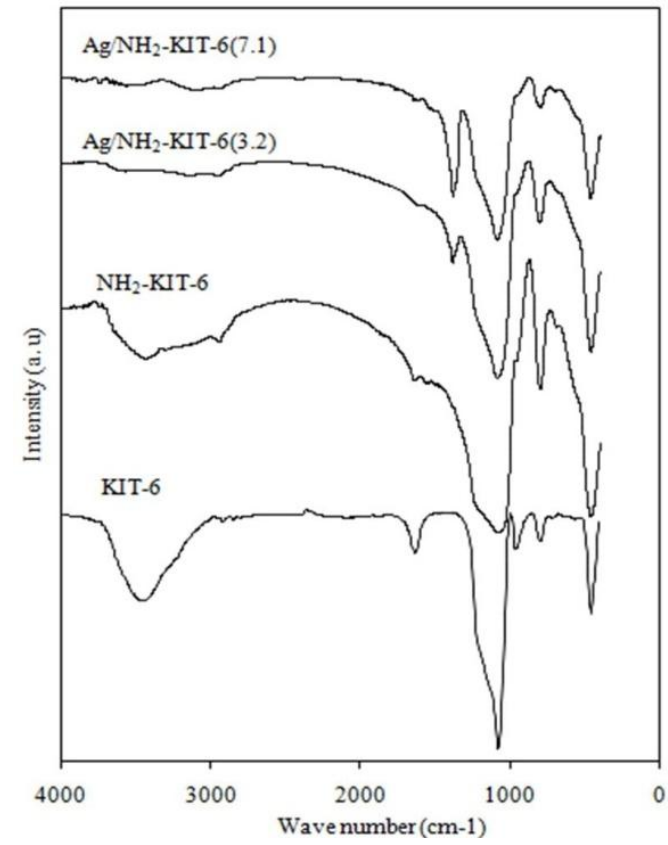

Fig. 2: FTIR spectra of calcined KIT-6, $\mathrm{NH}_{2}$-KIT-6, Ag/NH $2-\mathrm{KIT}-6$ (3.2 \& 7.1\%) materials.

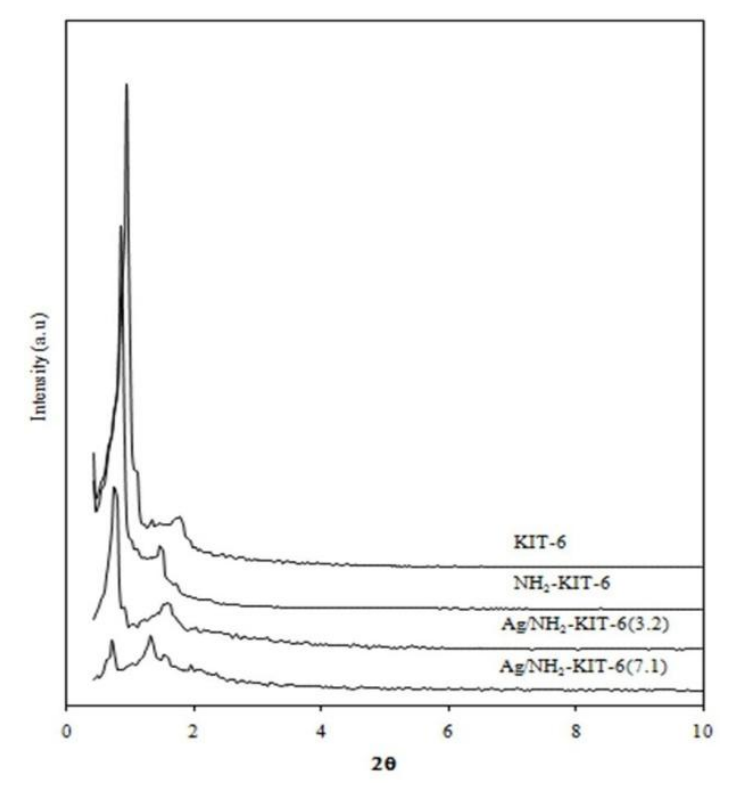

Fig. 3: Low XRD patterns for KIT-6, $\mathrm{NH}_{2-}$ KIT-6 and Ag/ $\mathrm{NH}_{2}$-KIT-6 (3.2 \& 7.1\%) materials. 


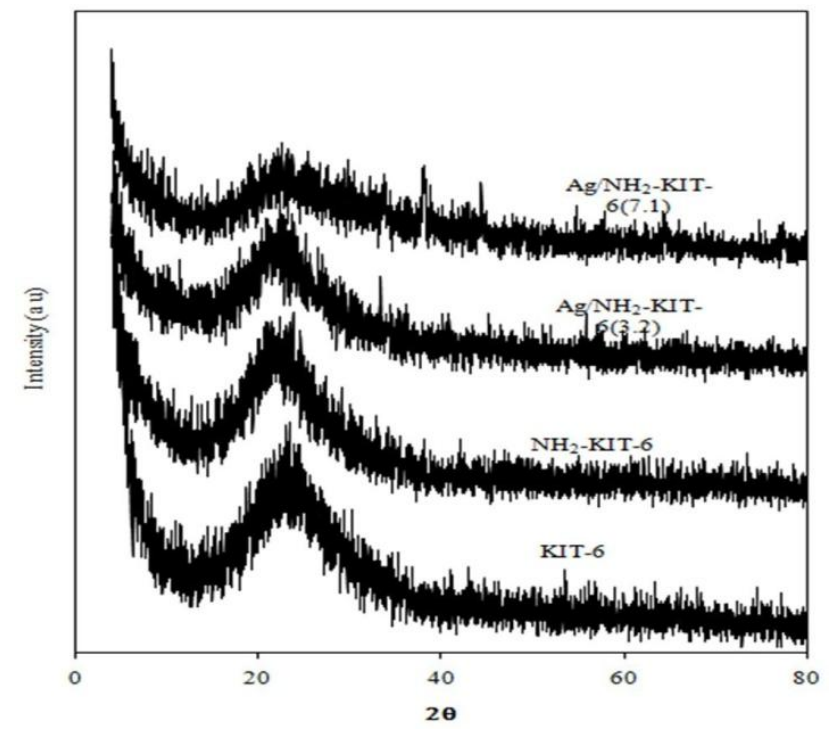

Fig. 4: High XRD patterns of KIT-6, $\mathrm{NH}_{2}-\mathrm{KIT}-6$ and $\mathrm{Ag} / \mathrm{NH}_{2}$-KIT $6(3.2 \& 7.1 \%)$ materials.

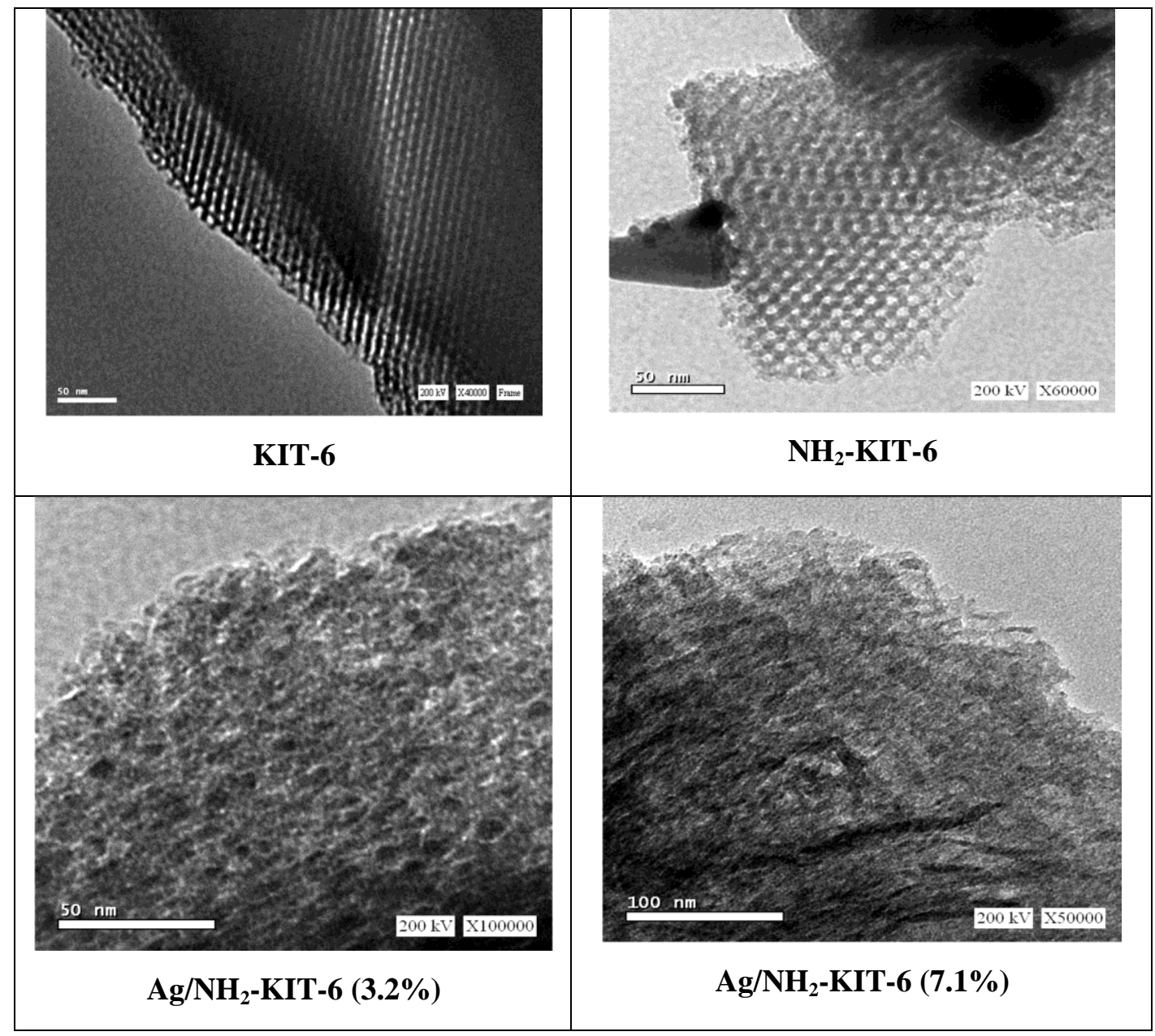

Fig. 5: High Resolution Transmission Electron Microscope images of KIT-6, $\mathrm{NH}_{2}$-KIT-6 and $\mathrm{Ag} / \mathrm{NH}_{2}-\mathrm{KIT}-6$ (3.2\&7.1) materials.

\section{Corresponding author: e-mail: habostash@gmail.com}


Table 1:The physicochemical characterization and textural of KIT-6, $\mathrm{NH}_{2}-\mathrm{KIT}-6$ and $\mathrm{Ag} / \mathrm{NH}_{2}$-KIT-6 (3.2 and 7.1\%)

\begin{tabular}{|c|c|c|c|c|c|c|}
\hline Sample & $d_{211}(\AA)$ & $\begin{array}{r}\mathrm{a}_{0}( \\
\mathrm{nm})\end{array}$ & $\overline{\mathrm{W}_{\mathrm{T}}}$ & $\begin{array}{c}\mathrm{S}_{\mathrm{BET}}{ }^{\mathrm{a}} \\
\left(\mathrm{m} 2 \mathrm{~g}^{-1}\right)\end{array}$ & $\begin{array}{c}\mathrm{D}_{\mathrm{p}}^{\mathrm{b}} \\
(\mathrm{nm})\end{array}$ & $\begin{array}{r}\mathrm{V}_{\mathrm{p}}(\mathrm{c} \\
\left.\mathrm{m}^{3} \mathrm{~g}^{-1}\right)\end{array}$ \\
\hline KIT-6 & 93.87 & 22.99 & 2.735 & 705 & 8.76 & 0.889 \\
\hline $\mathrm{NH}_{2}$-KIT-6 & 102.61 & 25.13 & 5.945 & 503 & 6.62 & 0.62 \\
\hline $\begin{array}{l}\mathrm{Ag} / \mathrm{NH}_{2}-\mathrm{KIT}- \\
6(3.2)\end{array}$ & 119.23 & 29.21 & 8.865 & 315 & 5.74 & 0.46 \\
\hline $\begin{array}{l}\mathrm{Ag} / \mathrm{NH}_{2}-\mathrm{KIT}- \\
6(7.1)\end{array}$ & 124.27 & 30.44 & 10.04 & 280 & 5.18 & 0.39 \\
\hline
\end{tabular}

$\mathrm{S}_{\mathrm{BET}}$, specificsurfacearea; $\mathrm{D}_{\mathrm{p}}$, porediameter; $\mathrm{W}_{\mathrm{T}}$, porewallthickness $\left[\mathrm{a}_{\mathrm{o}} / 2,\left(\right.\right.$ wherea $\left._{\mathrm{o}}=\quad \sqrt{6} \mathrm{a}\right]$

${ }^{a}$ Values obtained from XRD studies.

${ }^{\mathrm{b}}$ Values obtained from $\mathrm{N}$-ądsorption results.

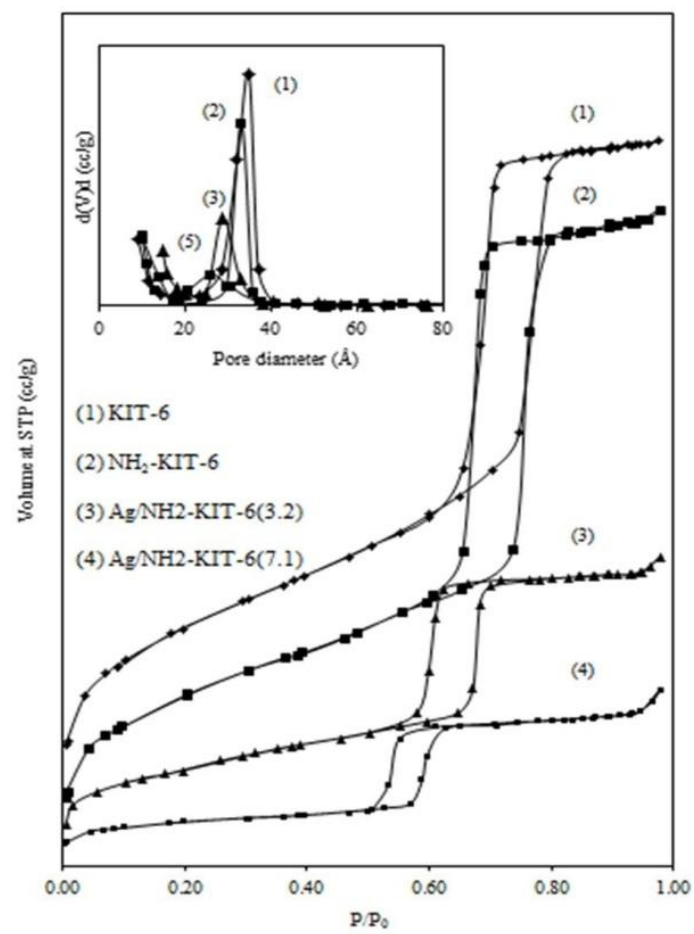

Fig. 6: Nitrogen adsorption/desorption and pore size distribution of KIT-6, $\mathrm{NH}_{2}-\mathrm{KIT}-6$ and $\mathrm{Ag} / \mathrm{NH}_{2}$-KIT$6(3.2 \& 7.1 \%)$ materials.

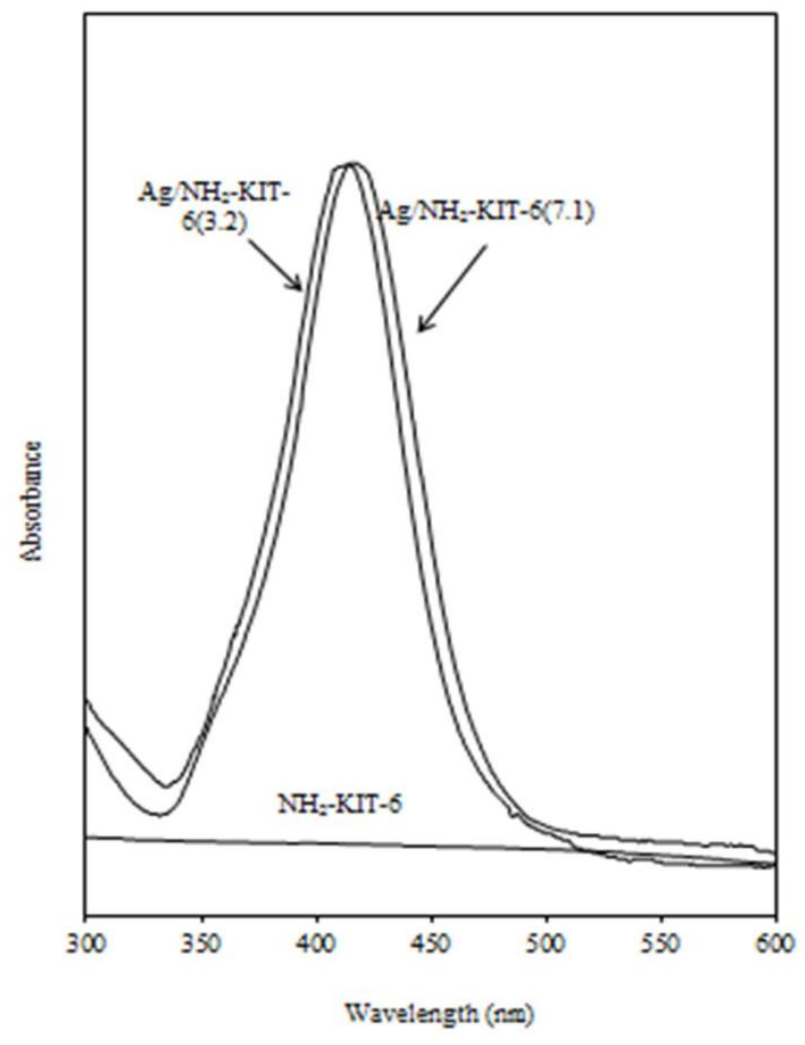

Fig. 7: UV-visible absorption spectra of NH2KIT-6, Ag/NH2-KIT-6(3.2\& $7.1 \%)$ materials. 

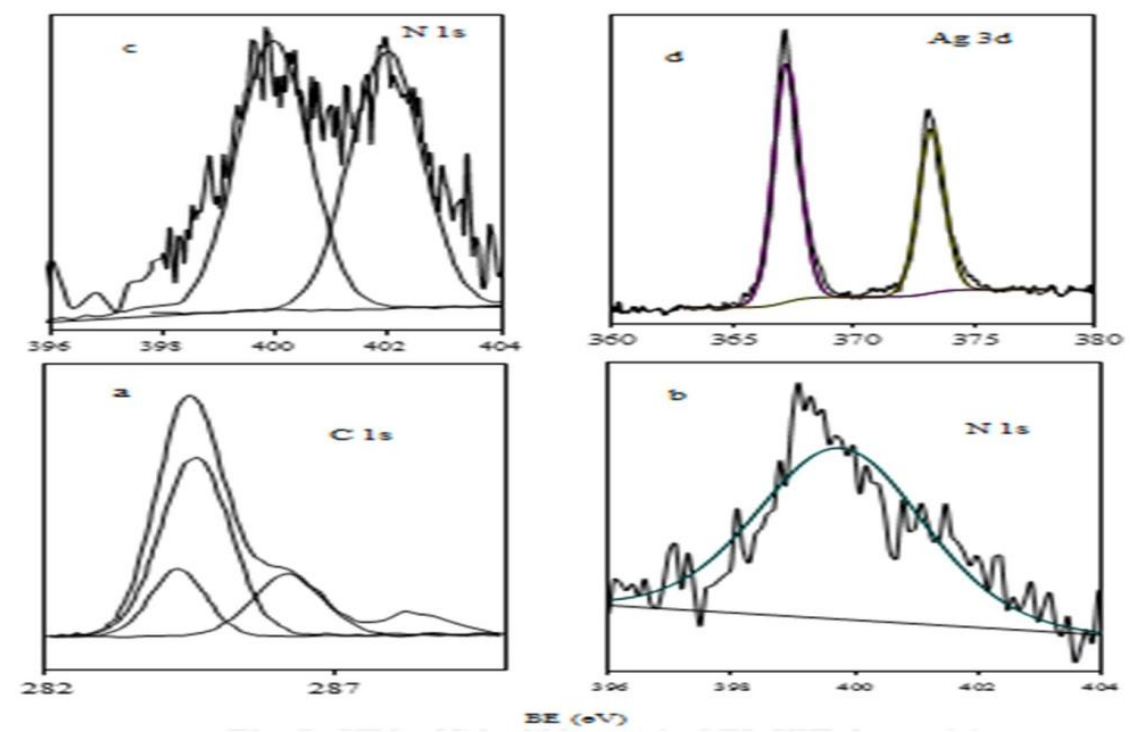

Fig. 8: XPS of a: C 1s, b\& c: $\mathrm{N} 1 \mathrm{~s}$ and d: Ag/NH2-KIT-6 (7.1\%) material.

\section{Antibacterial Activity}

In vitro antibiotic susceptibility test was performed against two bacterial strains, S. aureusas Gram positive \&Pseudomonas aeruginosaas Gram negative strains Table 2. Pseudomonas aeruginosawas found to be resistant to CFZ, NA and F while $S$. aureuswas found to be resistant to NA and SXT. The antibacterial activity was affected with the concentrations $3.2 \& 7.1 \%$ of $\mathrm{Ag}$ in $\mathrm{Ag} / \mathrm{NH} 2-\mathrm{KIT}-6(\mathrm{x})$. The maximum inhibition zone diameter obtained is 32 and $30 \mathrm{~mm}$ when using $7.1 \%$ against $P$. aeruginosaand $S$. aureusrespectively.

The present results showed that the mesoporous Ag/NH2-KIT-6(x) exhibited good antibacterial activity and inhibited the growth of $P$. aeruginosa and $S$. aureuseffectively. Whereas the meoporous silica-KIT- 6 and $\mathrm{NH}_{2}$-KIT- 6 exhibited no bacterial inhibitory effects due to the abscence of metal silver nanoparticles in the composite material. APTS modification procedure plays a very important role in the immobilization of silver nanoparticles onto $\mathrm{mSiO}_{2}$. Because the amino group of APTS could absorb a larger amount of Ag+ ions tightly through the complex and electrostatic interactions between $\mathrm{Ag}+$ ions and amino functional groups. However, there only a small amount of $\mathrm{Ag}+$ ions could be absorbed onto $\mathrm{mSiO}_{2} \mathrm{APTS}$ modification and the created Ag nanoparticles could easily break away from the channels of $\mathrm{mSiO}_{2}$ during the filtration and washing procedure (Shenet al., 2014). The synthesized AgNPs appeared to be highly dispersed on $\mathrm{NH}_{2}$-KIT6 and took the direction of KIT-6 pores, and the particle size distribution of mesoporousAgNPs was of 4-9 $\mathrm{nm}$. In general, for nanoparticles to be effective, their typical size should not be larger than $50 \mathrm{~nm}$. More precisely, mesoporoussilver nanoparticles with size between 10 and $15 \mathrm{~nm}$ have increased stability, biocompatibility and enhanced antimicrobial

\section{Corresponding author:}


activity(Yacamanet al., 2001). Some studies have revealed that the antibacterial action of AgNPs is more effective against $S$. aureusand K.pneumoniaewhen nanoparticles of smaller diameter $(<30 \mathrm{~nm})$ are used (Collins et al., 2010). The antibacterial effect of AgNPs as proposed is due to their smaller particles size that apparently has superior penetration ability into bacteria, especially in Gram-negative (Moroneset al., 2005)

Antimicrobial efficacy of AgNPs was evaluated by many researchers against a broad range of microbes, including MDR and non-MDR strains of bacteria, fungi, and viruses (Malarkodiet al., 2013). Nano-sized metal particles are now well-established as a promising alternate to antibiotic therapy because they possess unbelievable potential for solving the problem associated with the development of multidrug resistance in pathogenic microorganisms, hence also regarded as next-generation antibiotics (Raiet al., 2012).

Table 2:Antibacterial activityof $\mathrm{Ag} / \mathrm{NH} 2-\mathrm{KIT}-6(\mathrm{x})$ versus antibacterial activity of standardantibiotics against $S$. aureusandP.aeruginosa.

\begin{tabular}{|l|c|c|}
\hline \multirow{2}{*}{ Antibacterial agent } & \multicolumn{2}{|c|}{ Inhibtion zone (mm) } \\
\cline { 2 - 3 } & S. aureus & P. aeruginosa \\
\hline Ag/NH2-KIT-6 (7.1\%) & $30.0 \pm 0.0 \mathrm{a}$ & $32.0 \pm 2.0 \mathrm{a}$ \\
\hline Ag/NH2-KIT-6 (3.2\%) & $23.0 \pm 0.0 \mathrm{bc}$ & $25.0 \pm 0.0 \mathrm{~b}$ \\
\hline Cefodizime(CFZ) & $13.0 \pm 0.0 \mathrm{~d}$ & $0.0 \pm 0.0 \mathrm{f}$ \\
\hline Cefoperazone(CEP) & $29.0 \pm 1.0 \mathrm{a}$ & $17.0 \pm 0.0 \mathrm{~d}$ \\
\hline Streptomycin(S) & $23.0 \pm 0.0 \mathrm{bc}$ & $20.0 \pm 0.0 \mathrm{c}$ \\
\hline Nalidixi acid (NA) & $0.0 \pm 0.0 \mathrm{e}$ & $0.0 \pm 0.0 \mathrm{f}$ \\
\hline Neomysin(N) & $21.0 \pm 1.0 \mathrm{bc}$ & $15.3 \pm 0.6 \mathrm{e}$ \\
\hline $\begin{array}{l}\text { Sulfamethoxazole- } \\
\text { trimethoprim(SXT) }\end{array}$ & $0.0 \pm 0.0 \mathrm{e}$ & $17.0 \pm 0.0 \mathrm{~d}$ \\
\hline Chloramphenicol(C) & $24.0 \pm 1.0 \mathrm{~b}$ & $17.0 \pm 0.0 \mathrm{~d}$ \\
\hline Colifuran(F) & $18.7 \pm 8.1 \mathrm{c}$ & $0.0 \pm 0.0 \mathrm{f}$ \\
\hline F value & $\mathbf{4 9 . 6 7 1 * * *}$ & $\mathbf{8 4 3 . 5 9 0 * * *}$ \\
\hline
\end{tabular}

The antimicrobial activity of Ag /NH2-KIT-6 (x) was also evaluated using the macrodilution broth susceptibility method. MIC and MBC of silver nanoparticles shown best results with the concentration $7.1 \%$ of $\mathrm{Ag} / \mathrm{NH} 2-\mathrm{KIT}-6$ than the concentration 3.2\% of Ag/NH2-KIT-6 (Table 3). The MIC and MBC for the Ag /NH2-KIT-6 (3.2\%) against tested bacteria P. aeruginosaand $S$. aureusdiffer in their values, but MIC equals $\mathrm{MBC}$ at the concentration (7.1\%).

The concentration ofAg/NH2-KIT-6 (7.1\%) shows 0.0045 and $0.041 \mu 1 / \mathrm{ml}$ for both MIC and MBC against $P$. aeruginosaand $S$. aureusrespectively, i.e.completely inhibited, which indicated that the MIC and MBC ofAg/NH2-KIT- 6(7.1\%) are equal (Table 3). The obtained result agree with Ansari etal. (2011)

\section{Corresponding author:}

e-mail: habostash@gmail.com 
whom showed that the AgNPs of 5-10 nm dimension display both bacteriostatic as well as bactericidal effects against $S$. aureus, MSSA and MRSA.

Gram-negative bacteria are more sensitive against nano $\mathrm{Ag} / \mathrm{NH}_{2} \mathrm{KIT}-6$ than gram-positive bacteria, also Klapiszewskiet al .(2015) and Yuan et al. (2017) demonstrated that, AgNPs were more effective against Gram-negative $P$. aeruginosathan Gram-positive $S$. aureus, which could be explained by differences in membrane structure and the cell wall composition, which influence bacterial susceptibility to AgNPs.

Table 3: The MIC and MBC of mesoporous silver nanoparticles (Ag/NH $\mathrm{NH}_{2}-\mathrm{KIT}-6$ (3.2 and $7.1 \%$ ) against $P$. aeruginosaand $S$. aureus.

\begin{tabular}{|c|c|c|c|}
\hline \multirow{2}{*}{\multicolumn{2}{|c|}{$\begin{array}{c}\mathbf{A g} / \mathrm{NH}_{2}-\mathrm{KIT}-6(\mathrm{x}) \\
(\mu \mathrm{g} / \mathrm{ml})\end{array}$}} & \multicolumn{2}{|c|}{ Tested Bacterium } \\
\hline & & \multirow{2}{*}{$\begin{array}{r}\text { P. aeruginosa } \\
0.0045\end{array}$} & \multirow{2}{*}{$\begin{array}{r}\text { S.aureus } \\
0.041\end{array}$} \\
\hline 320 & MIC & & \\
\hline & MBC & 0.013 & 0.37 \\
\hline \multirow[t]{2}{*}{$7.1 \%$} & MIC & 0.0045 & 0.041 \\
\hline & MBC & 0.0045 & 0.041 \\
\hline
\end{tabular}

The electron micrographs of the surface structures by TEM of $P$. aeruginosaand $S$. aureustreated and untreated cells with $\mathrm{Ag} / \mathrm{NH}_{2}-\mathrm{KIT}-6(7.1 \%)$ are shown in Fig 10. The treated bacterial cells were significantly changed, and major damage was observed in the outer cell membrane. Nanoparticles that accumulated in the membrane as well as some penetrating the cells can also be discerned in the TEM micrograph.

A recent report has demonstrated the antibacterial activity of mesoporous silica silver nanoparticles on both Gram positive and Gram negative microbes. The mechanism of the antibacterial activity of mesoporous silica nanoparticles was attributed to the electrostatic interaction of phosphate groups on the microbial cell wall and the cationic head group of the mesoporous silica nanoparticles. Also, the organic tail region embeds itself in the lipid bilayer. This, in turn, leads to the free flow of electrolytes out of the microbe and causes the cell death. This is believed to be the mechanism of cell death (Xia et al., 2009 and Vithiyaet al.,2014).

\section{Corresponding author: \\ e-mail: habostash@gmail.com}




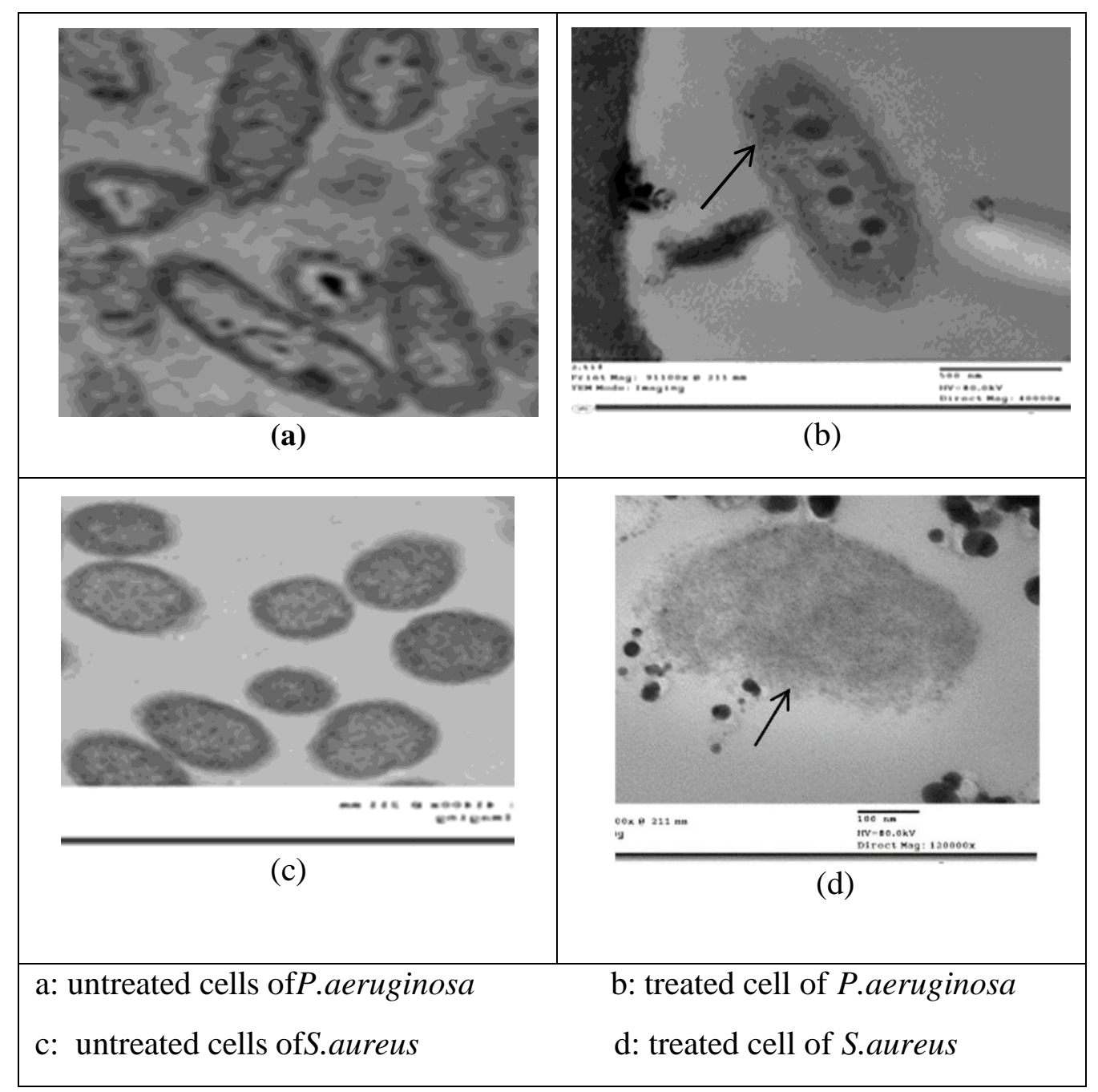

Fig. 10: TEM micrographs of the action of mesoporous $\mathrm{Ag} / \mathrm{NH}_{2}-\mathrm{KIT}-6$ (7.1\%) on the ultrastructure of $P$. aeruginosaand $S$. aureuscells.

\section{Conclusion}

In this study, antibacterial activity of mesoporous Ag/NH2-KIT-6(x) nanoparticles synthesized using a chemical reduction method was tested against $\mathrm{P}$. aeruginosa and $\mathrm{S}$. aureus. The obtained results confirmed that different concentrations of mesoporous $\mathrm{Ag} / \mathrm{NH} 2-\mathrm{KIT}-6(\mathrm{x})$ nanoparticles have very strong inhibitory properties in comparison with standard antibiotics. Different degrees of sensitivity were shown among the bacteria, probably due to the difference in the structure and/or composition of their cell walls. These pathogens are very dangerous for human as it is associated with many systemic diseases. From TEM analysis it could be observed that when this interaction occurred, the mesoporous Ag/NH2-KIT-6(x) nanoparticles were able to cause microbial cell membrane damage. It is wished that in near future using synthetic or purified forms of these mesoporous nanoparticles could be easily fight pathogenic microbes and improve health.

\section{Corresponding author: e-m ail:habostash@gmail.com}




\section{$\underline{\text { References }}$}

$>$ Chen, M.; He, X.; Wang, K.; He, D.; Yang, S.; Qiu, P. and Chen, S. (2014): A pH-responsive polymer/mesoporous silica nanocontainer linked through an acid cleavable linker for intracellular controlled release and tumor therapy in vivo. J. Mater. Chem. B 2:428-36.

> Coates, J. (2000): Interpretation of infrared spectra: A practical approach, R. A. Meyers, ed., Encyclopedia of Analytical Chemistry, W.John\& Sons Ltd, Chichester, pp.10815-10837.

> Collins, T. L.; Markus, E. A.; Hassett, D. J. and Robinson, J. B. (2010): The effect of a cationic porphyrin on Pseudomonas aeruginosabiofilms. Curr. Microbiol. 61:411-416.

> EL-Batal, A.I.; Amin, M.A.; Shehata, M.M.K. and Hallol, M. (2013): Synthesis of Silver nanoparticles by Bacillus stearothermophilususing Gamma Radiation and their antimicrobial activity. World Appl. Sci. J. 22 (1):01-16.

$>$ Feng, Q.L.; Wu, J.; Chen, G.Q.; Cui, F.Z.; Kim, T.N. and Kim, J.O. (2000): A mechanistic study of the antibacterial effect of Silver ions onEscherichia coli and Staphylococcus aureus. J. Biomed. Mater. Res. 4:662-8.

$>$ Ferraria, A.M.; Boufi, S.; Battaglinis, N.; Botelho do Regot, A.M. and ReiVilars, M. (2010): Hybrid systems of Silver nanoparticles generated on cellulose surfaces. Langmuir, 26(3):1996-2001.

> Franci, G.; Falanga, A.; Galdiero, S.; Palomba, L. ;Rai, M.; Morelli, G.; and Galdiero, M. (2015): Silver nanoparticles as potential antibacterial agents. Molecules, 20:8856-8874.

$>$ Gebeyehu, M.B.; Chang, Y. Abay, A.K.; Chang, S.;Lee, J.; Wu, C.; Chiang, T. and Murakami, R. (2016): Fabrication and characterization of continuous silver nanofiber/polyvinylpyrrolidone (AgNF/PVP) core-shell nanofibers using the coaxial electrospinning process. RSC Advances, 6(59): 54162-54168.

$>$ Grigor'eva, A.; Saranina, I.; Tikunova, N.; Safonov, A.; Timoshenko, N.andRebrov, A. and Ryabchikovoc, E. (2013): Fine mechanisms of the interaction of Silver nanoparticles with the cells of Salmonella typhimuriumand Staphylococcus aureus. Biometals,26(3):479-488.

$>$ Hassan , H.M.A.; Saad, E.M.; Soltan, M.S.; Betiha, M.A.; Butler, I.S.andMostafa S.I. (2014): A Palladium (II) 4-hydroxysalicylidene Schiffbase complex anchored on functionalized MCM-41: An efficient heterogeneous catalyst for the epoxidation of olefins. App. Catal. A. 488:148159.

Corresponding author:

e-mail: habostash@gmail.com 
> Hassan, H.M.A.; Betiha, M.A.; Khder, S.; Mostafa, M. and Gallab, M. (2016): Hafnium pentachloride ionic liquid for isomorphic and postsynthesisof HfKIT-6 mesoporous Silica: catalytic performances of Pd/SO42-/HfKIT-6. J. Porous. Mater. 23: 1339-1351.

> Iconaru, S.L.; Prodan, A.M.; Le Coustumer, P. and Predoi, D. (2012): Synthesis and antibacterial and antibiofilm activity of Iron Oxide Glycerol nanoparticles obtained by coprecipitation method. J. Chemist. 2013(2013): 16.

> Kheiralla, Z.M.H.; Rushdy, A. A.; Betiha, M.A. and Yakob N. A.N. (2014): High-performance antibacterial of montmorillonite decorated with silver nanoparticles using microwave assisted method. J. Nanopart. Res.16:2560.

$>$ Kim, K.; Kim, H.S. and Park, H.K. (2006): Facile method to prepare surfaceenhanced-Raman-scattering-active $\mathrm{Ag}$ nanostructures on silica spheres. Langmuir, 22:8083-8088.

> Klapiszewski, L.; Rzemieniecki, T.; Krawczyk, M.; Malina, D.; Norman, M.; Zdarta, J.; Majchrzak, I.; Dobrowolska, A.; Czaczyk, K. and Jesionowski, T. ( 2015): Kraft lignin/silica-AgNPs as a functional material with antimicrobial activity. Colloids. Surf. B Biointerfaces, 134:220-228.

$>$ Klevens, R.M.; Morrison, M.A.; Nadle, J.; Petit, S.; Gershman, K.; Ray, S.; Harrison, L.H.; Lynfield, R.; Dumyati, G. and Townes, J.M.( 2007): Invasive methicillin-resistant Staphylococcus aureusinfections in the United States. JAMA.298:1763-1771.

> Han, F.; Bai, Y.; Lin, R.; Yad, B.; Qi, Y.; Lun, N. and Zhang, J. (2011): Template-Free Synthesis of Interconnected Hollow Carbon Nanospheres for High-Performance Anode Material in Lithium-Ion Batteries. Adv. Energy Mater. 1(5):798-801.

$>$ Malarkodi, C.; Rajeshkumar, S.; Paulkumar, K.; GnanaJobitha, G.; Vanaja, M. and Annadurai, G. (2013): Biosynthesis of semiconductor nanoparticles by using sulfur reducing bacteria Serratianematodiphila. Adv. Nano. Res. 1:83-91.

> McCusker, L. B. and Baerlocher, C. (2001): In introduction to Zeolite Science and practice, H.VanBekkum, E. M. Flanigen, P. A. Jacobs, and J. C. Jansen, eds. Amsterdam: Elsevier, pp. 137,37.

$>$ Morones, J. R.; Elechiguerra, J. L.; Camacho, A.; Holt, K.; Kouri, J. B.; Ramírez, J. T. andYacaman, M. J. (2005): The bactericidal effect of silver nanoparticles. Nanotechnology, 16:2346-2353.

Corresponding author:

e-mail: habostash@gmail.com 
$>$ Natarajan, S. K. and Selvaraj, S. (2014): Mesoporous Silica nanoparticles: importance of surface modifications and its role in drug delivery. RSC Adv. 4: $14328-14334$.

$>$ Qasim, M.; Ananthaiah, J.; Dhara, S.; Paik, P. and Das, D. (2014): Synthesis and characterization of ultra-fine colloidal Silica nanoparticles Adv. Sci. Eng. Med. 6:965-973.

> Qian, L.; Ren,Y.; Liu,T.; Pan, D.; Wang, H. and Chen, G. (2012): Influence of KIT-6's pore structure on its surface properties evaluated by inverse gas chromatography. Chem. Eng. J. 213 :186-194.

$>$ Rai, M. and Duran, N. (2011): Metal nanoparticles in microbiology, SpringerVerlag. BerlinHeidelberg.

$>$ Rai, M.K.; Deshmukh, S.D.; Ingle, A.P. and Gade, A.K. (2012): Silver nanoparticles: The powerful nanoweapon against multidrug-resistant bacteria. J. Appl. Microbiol. 112:841-852.

$>$ Rai, M.; Deshmukh, S.D.; Ingle, A.P.; Gupta, I.R.; Galdiero, M. and Galdiero, S. (2016): Metal nanoparticles: The protective nanoshield against virus infection. Crit. Rev. Microbiol. 24(1):46-56.

> Karthikeyan, R.; Amaechi, B.T.; Rawls, H.R. and Lee, V.A. (2011): Antimicrobial activity of nanoemulsion on cariogenic Streptococcus mutans. Arch.Oral Biol.56:437-445.

$>$ Ruedas-Rama, M. J.; Walters, J. D.; Orte, A. and Hall, E. A. H. (2012): Fluorescent nanoparticles for intracellular sensing: A review. Anal. Chim. Acta, 751:1-23.

$>$ Ruparelia, J. P.; Chatterjee, A. K.; Duttagupta, S. P. and Mukherji, S. (2008): Strain specificity in antimicrobial activity of Silver and Copper nanoparticles .ActaBiomater .4(3):707-716.

$>$ Sajab, M.S.; Chia, C.H.; Zakaria, S.; Jani, S.M.; Ayob, M.K.; Chee, K.L.; Khiew, P.S. and Chiu, W.S. (2011): Citric acid modified kenaf core fibres for removal of methylene blue from aqueous solution. Bioresour. Technol. 102: 7237-7243.

$>$ Shen, Q. J.; Wang, H.; Yang, X.; Ding, Z.; Luo, H.; Wang, C.; Pan, J.; Sheng, and Cheng, D. (2014): J.Non-Cryst. Solids, 391:112-116.

\section{SPSS (2006). SPSS base 15.0 User's guide. SPSS inc., Chicago,USA.}

$>$ Sweet, M.J. and Singleton, I. (2011): Silver nanoparticles: A microbial perspective. Adv. Appl. Microbiol. 77:115-133. 
$>$ Taraszkiewicz, A.; Fila, G.; Grinholc, M. and Nakonieczna, J. (2012): Innovative strategies to overcome biofilm resistance. Biomed. Res. Int. 2013 (2013):1-13.

$>$ Walker, B.; Barrett, S.; Polasky, S.; Galaz, V.; Folke, C.; Angstroms G.; Ackerman, F.; Arrow, K.; Carpenter, S.; Chopra, K.; Daily, G.; Ehrlich, P.; Hughes,T.; Kautsky, N.; Levin,S.; Maler, K.G.; Shogren, J.; Vincent, J.; Xepapadeas, T. and de Zeeuw, A.(2009): Environment. Looming globalscale failures and missing institutions. Science, 325:1345-1346.

> Wang, X.; Tseng, Y.; Chan, J.C.C. and Cheng, S. (2005): Catalytic applications of aminopropylatedmesoporous Silica prepared by a template-free route in flavanones synthesis. J. Catal. 233:266-275.

$>$ Weber, C.; Coester, C.; Kreuter, J. and Langer, K. (2000): Desolvation process and surface characterisation of protein nanoparticles. Int. J. Pharm. 194: 91-102.

$>$ Wu, S.; Mou, C. and Lin, H. (2013): Synthesis of mesoporoussilica nanoparticles. Chem. Soc. Rev. 42 :3862-3875.

$>$ Xia, T.; Kovochich, M.; Liong, M.; Meng, H.; Kabehie, S.; George, S.; Zink, J.I. and Nel, A.E. (2009): Polyethyleneimine coating enhances the cellular uptake of mesoporous silica nanoparticles allowed safe delivery of siRNA and DNA constructs. ACS Nano. 3(10):3273-3286. Vithiya, K.; Kumar, R. and Sen, S. (2014): Bacillus sp. Mediated extracellular synthesis of silver nanoparticles. Int. J. Pharm. Sci.6:525-7

> Yacaman, M. J.; Ascencio, J. A.; Liu, H. B. and Gardea-Torresdey, J. (2001): Structure shape and stability of nanometric sized particles. J. Vacuum. Sci. Technol. B. Microelectron. Nanometer. Struct. 19:1091-1103.

$>$ Yildirim, A.; Demirel, G. B.; Erdem, R.; Senturk, B.; Tekinay, T. and Bayindir, M. (2013): Pluronic polymer capped biocompatible mesoporous Silica nanocarriers. Chem. Commun. 49:9782-9784.

Yuan, Y.; Peng, Q. and Gurunathan, S. (2017): Effects of Silver nanoparticles on multiple drug-resistant strains of Staphylococcus aureusand Pseudomonas aeruginosafrom mastitis-infected goats: An alternative approach for antimicrobial therapy. Int. J. Mol. Sci. 18:569.

Corresponding author:

e-mail: habostash@gmail.com 
التأثير الميكروبى المضاد لجزيئات الفضة والسليكا المسامية النانونية على سلالات من البكتريا المقاومة للمضادات الحيوية

1 1ناء صبحي زكي ، 1زينب محمد حسن خير الله ، 1عبير احمد رشدي ، 1حنان بشير ابوسطاش ، محمد احمد بطيحة2 1 ـ ق قسم النبات ـ كلية البنات لللأداب و العلوم و التربية- جامعة عين شمس ـ أسماء فهمي ـ القاهرة ـ مصر r - بعهذ بحوث البترول - القاهرة- مصر

الخلاصة

تم در اسة النشاط الميكروبى لجزيئات النانونية المخلقة بطريقة الأختزال الكيميائى ضد

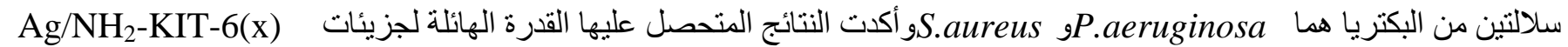
النانونية بمختلف تركيز ات الفضة بها على تثبيط النمو الميكروبى لكلا من S.aureus و P.aeruginosa مقارنة بالمضادات الحيوية التى تم إستخدامها.

كما لوحظ وجود إختلاف فى درجة حساسية كلا الميكروبين للجزيئات النانونية وربما يعود هذا إلى إختلاف تركيب الجدر الخلوية

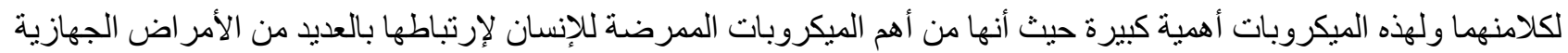
ويتضح من صور الميكروسكوب النافذ مدى التلف التى أحدثته جزيئات Ag/NH2-KIT-6(x) النانونية للأشية الخلوية.

mesoporous

نأمل فى المستقبل القريب إستخدام أنواع مخلقة ونقية من الجزيئات النانونية فى صورة الممرضة للإنسان. 